\title{
Pengembangan paket ipa terpadu berbasis learning cycle (LC) 5e untuk meningkatkan kemampuan berpikir kreatif siswa SMP/MTs kelas VII tema pemanasan global
}

\author{
Hana Naqiyya Nada, Supriyono Koes H*, Safwatun Nida \\ Universitas Negeri Malang, Jl. Semarang No. 5 Malang, Jawa Timur, Indonesia \\ *Penulis korespondensi, Surel: supriyono.koeshandayanto.fmipa@um.ac.id
}

Paper received: 01-03-2021; revised: 15-03-2021; accepted: 31-03-202

\begin{abstract}
Abstrak
Perancangan pembelajaran yang sesuai dengan prinsip pembelajaran IPA membutuhkan bahan ajar untuk menunjang proses pembelajaran. Learning cycle 5e merupakan model pembelajaran yang tepat digunakan dalam pembelajaran IPA karena melibatkan siswa secara aktif dalam proses pembelajaran, sehingga mereka lebih mudah mengungkapkan gagasannya. Gagasan yang muncul dapat merangsang kemampuan berpikir kreatif siswa. Tujuan dari penelitian ini adalah menghasilkan produk berupa Paket IPA Terpadu berbasis Learning Cycle (LC) 5e untuk meningkatkan kemampuan berpikir kreatif siswa SMP/MTs kelas VII Tema Pemanasan Global yang layak dan valid. Model penelitian yang digunakan di dalam penelitian dan pengembangan ini adalah model pengembangan ADDIE. Kelayakan produk yang dikembangkan diperoleh dari uji kelayakan dan uji keterbacaan terbatas. Berdasarkan hasil uji kelayakan Paket IPA Terpadu dan uji keterbacaan terbatas yang dilakukan, produk yang dikembangkan telah memenuhi kriteria sangat layak dan valid untuk diuji keefektivitasannya agar dapat digunakan dalam pembelajaran IPA SMP kelas VII pada tema pemanasan global.
\end{abstract}

Kata kunci: paket IPA terpadu; learning cycle 5e; berpikir kreatif; pemanasan global

\section{Pendahuluan}

Berdasarkan Peraturan Menteri Pendidikan dan Kebudayaan Nomor 65 Tahun 2013 tentang Standar Proses Pendidikan Dasar dan Menengah, proses pembelajaran IPA diselenggarakan secara interaktif, inspiratif, menyenangkan, menantang, memotivasi peserta didik untuk berpartisipasi aktif. Proses pembelajaran IPA juga diharapkan memberikan ruang yang cukup bagi prakarsa, kreativitas, dan kemandirian. Selain ruang yang cukup pembelajaran akan efektif bila sesuai dengan bakat, minat, dan perkembangan fisik serta psikologis peserta didik. Menurut Adisenjaja dan Romlah (2007), pembelajaran sains lebih menekankan kepada aktifitas siswa, mengurangi kegiatan yang fokus pada ingatan berupa fakta, dan lebih menekankan keterampilan proses sains untuk menemukan konsep.

Berdasarkan wawancara dan observasi di salah satu SMP di kabupaten Malang tepatnya di Turen, seringkali guru kesulitan dalam proses belajar mengajar, karena kurikulum menuntut siswa lebih aktif menemukan permasalahan yang kemudian dipecahkan sendiri untuk mencapai tujuan pembelajaran. Guru dituntut sebagai fasilitator yang membantu siswa menfasilitasi pembelajaran. Guru tidak menerangkan pembelajaran, tetapi membantu siswa untuk memecahkan masalahnya sendiri. Siswa belum terbiasa menggunakan pembelajaran saintifik sehingga belum mampu membangun konsepnya sendiri. Siswa selalu bertanya pada guru padahal petunjuk yang diberikan sudah jelas.

Perancangan pembelajaran dibutuhkan untuk menciptakan proses pembelajaran yang sesuai dengan prinsip pembelajaaran IPA. Perancangan pembelajaran ini dibuat untuk memudahkan guru dalam penyusun strategi yang digunakan guna tercapainya kompetensi 
siswa. Perancangan pembelajaran dibutuhkan bahan ajar untuk menunjang proses pembelajaran. Adisenjaja dan Romlah (2007) mengemukakan dalam jurnalnya bahwa buku ajar atau buku teks siswa sangat membantu proses pembelajaran. Buku ajar digunakan untuk membantu guru dalam memandu pelajaran baik pembelajaran yang diselenggarakan di sekolah atau di rumah.

Bahan ajar yang disusun harus sesuai tuntutan kurikulum dengan mempertimbangkan kebutuhan siswa, yakni bahan ajar yang sesuai dengan karakteristik siswa. Bahan ajar diharapkan mampu membantu siswa belajar menemukan konsep sendiri dan mengurangi ketergantungannya terhadap guru. Bahan ajar yang baik harus memberikan makna yang dapat tersampaikan pada peserta didik (Bahtiar, 2015). Berdasarkan hal tersebut, maka bahan ajar yang digunakan dalam proses pembelajaran harus sesuai dengan kurikulum 2013 yang digunakan saat ini.

Berdasarkan kurikulum 2013, pembelajaran learning cycle merupakan pembelajaran yang dapat meningkatkan kemampuan berpikir kritis siswa. Pembelajaran dengan model ini juga mampu membuat siswa berperan aktif untuk membangun pengetahuan mereka sendiri (Sari, 2013). Pembelajaran learning cycle merupakan salah satu model belajar dengan basis konstruktivisme yang membuat siswa mampu mengkonstruk sendiri pengetahuannya. Berdasarkan penelitian yang dilakukan oleh Astutik (2012) dan Sumarni (2010) penggunaan pembelajaran learning cycle dapat meningkatkan hasil belajar siswa. Berdasarkan penelitian oleh Santika dkk (2016) pembelajaran learning cycle yang diterapkan pada materi perubahan lingkungan juga terbukti dapat meningkatkan kemampuan berpikir kreatif siswa.

Menurut Sari (2014: 2) dapat ditarik hubungan antara pendekatan scientific 5M dan learning cycle 5E sebagai berikut. (1) mengamati termasuk dalam fase Engangement (2) menanya termasuk dalam fase Exploration (3) mencoba termasuk dalam fase Explanation (4) mengasosiasi termasuk dalam fase Elaboration (5) mengkomunikasikan termasuk dalam fase Evaluation. Bahan ajar dengan tema pemanasan global yang telah ada berbentuk majalah dan juga buku saku (Asfuriyah dan Nuswowati, 2015. Yuliani dan Herlina, 2015). Pada kesempatan kali ini bahan ajar tema pemanasan global yang akan dikembangkan berbentuk paket buku guru dan siswa.

Pendidikan di sekolah diarahkan tidak hanya pada penguasaan konsep, akan tetapi juga peningkatan kemampuan dan keterampilan berpikir siswa (Sadia, 2014: 19). Khususnya keterampilan berpikir tingkat tinggi yaitu berpikir kritis dan berpikir kreatif. Pembelajaran learning cycle merupakan salah satu model pembelajaran yang memberi peluang untuk siswa mampu mengembangkan kemampuan berpikir kreatif. Menurut Munandar (1999: 43) pengembangan kreatifitas perlu dipupuk sejak dini kepada peserta didik agar memiliki kemampuan untuk melihat peluang penyelesaian masalah. Adapun tujuan dari berpikir kreatif ini siswa memiliki daya saing yang tinggi agar mampu berkompetisi di era global.

Pembelajaran learning cycle berkaitan erat dengan kemampuan siswa untuk berpikir kreatif. Kreatifitas siswa dapat dilihat dari bagaimana siswa memprediksi fenomenafenomena yang akan dibuktikan pada tahap explorasi. Mulai dari menanya, memberikan gagasan, memiliki rasa ingin tahu yang dalam, berani dan bebas dalam berpendapat.

Salah satu tema pada pembelajaran IPA adalah Pemanasan Global. Tema ini berisi penyebab terjadinya pemanasan global dan juga dampaknya bagi lingkungan. Besarnya 
dampak pemanasan global sudah dirasakan oleh siswa. Sangat penting untuk mengajarkan konsep pemanasan global sejak dini. Pembelajaran di kelas tentang pemanasan global menjadi salah satu upaya sosialisasi dini tentang dampak pemanasan global agar dapat menemukan solusi yang tepat (Asfuriyah dan Nuswowati, 2015; Santoso, 2011).

Bahasan dari tema pemanasan global berangkat dari kejadian nyata yang dialami siswa. Diperlukan pemahaman tentang konsep-konsep sains untuk menyelesaikan masalah yang ada di masyarakat. Tema ini sangat luas sehingga cakupan pembelajarannya bisa ditinjau dari segi sosial dan juga saintifik (Subiantoro, dkk, 2012; Rahayu, 2015; Hendri dan Defianti, 2015)

Tema pemanasan global juga menjadi dasar untuk siswa peduli pada lingkungan. Aplikasi dari tema ini diharapkan dapat membangun kreatifitas siswa mendukung Peraturan Menteri Lingkungan Hidup Nomor 05 Tahun 2013 tentang Pedoman Pelaksanaan Program Adiwiyata. Berdasarkan uraian tersebut dilakukan penelitian pengembangan dengan judul "Pengembangan Paket IPA Terpadu Berbasis Learning Cycle (LC) 5E untuk Meningkatkan Kemampuan Berpikir Kreatif Siswa SMP/MTs Kelas VII Tema Pemanasan Global".

\section{Metode}

Langkah-langkah yang digunakan dalam penelitian pengembangan ini mengadaptasi langkah-langkah model Addie. Terdiri dari 5 tahap, yaitu Analyze, Design, Develop, Implementation, Evaluation (Branch, 2009). Tahap analyze terdiri dari analisis kerja dan analisis kebutuhan. Tahap design terdiri dari merumuskan tujuan pembelajaran, pemilihan materi, kegiatan dan media, serta perencanaan penilaian. Tahap develop terdiri dari menyiapkan bahan, merancang produk dan instrumen. Tahap implementation yang dilakukan yaitu implementasi terbatas dengan uji validasi dan uji keterbacaan terbatas. Tahap evaluation yang dilakukan yaitu evaluasi formatif.

Desain uji coba penelitian ini meliputi kegiatan perbaikan produk dan uji coba skala kecil. Uji coba dilakukan kepada 1 guru IPA SMP dan 10 siswa SMP kelas VII. Jenis data yang diperoleh adalah data kuantitatif dan kualitatif. Instrumen yang digunakan untuk memperoleh data adalah dengan menggunakan lembar validasi ahli media, lembar validasi materi, dan lembar validasi keterbacaan. Lembar validasi dibuat dalam bentuk angket. Angket yang dibuat untuk lembar validasi ahli media, dan lembar validasi keterbacaan produk menggunakan skala Likert yang mencakup skala berperingkat 1 sampai 5 . Lembar validasi kebenaran materi menggunakan angket dengan menggunakan skala Guttman yaitu keterangan "YA" atau "TIDAK".

Teknik analisis data yang digunakan terdiri dari teknik analisis pada media dan teknik analisis pada instrumen evaluasi. Teknik analisis pada media menggunakan teknik analisis persentase.

\section{Hasil dan Pembahasan}

\subsection{Hasil Uji Kelayakan dan Kevalidan Produk}

Produk yang dihasilkan terdiri dari buku siswa dan buku panduan guru. Uji kelayakan paket IPA Terpadu terdiri dari uji kelayakan isi, kelayakan paket IPA terpadu dalam meningkatkan kemampuan berpikir kreatif siswa, kelayakan penyajian 
buku siswa, dan kelayakan panduan guru. Selain itu terdapat pula uji validitas materi yang meliputi kebanaran fakta dan konsep. Kegiatan uji kelayakan isi buku siswa menghasilkan data kuantitatif yang dapat dilihat pada Tabel 1.

Tabel 1. Hasil Uji Kelayakan Isi Buku siswa

\begin{tabular}{lll}
\hline \multirow{2}{*}{ No } & \multirow{2}{*}{ Aspek yang dinilai } & $\begin{array}{l}\text { Persentase } \\
\text { Rata-rata (\%) }\end{array}$ \\
\hline 1 & Keluasan Materi & 80,00 \\
2 & Kedalaman Materi & 75,00 \\
\hline 3 & Keakuratan Fakta dan Konsep & 75,00 \\
4 & Keakuratan Ilustrasi & 75,00 \\
5 & Kesesuaian dengan perkembangan ilmu & 86,80 \\
6 & Berbasis Learning Cycle 5e & 84,00 \\
\hline Rerata & & 79,20 \\
\hline
\end{tabular}

Uji validasi materi untuk memvalidasi kebenaran fakta dan konsep dapat dilihat pada tabel 2

Tabel 2. Hasil Uji Validasi Kebenaran Fakta dan Konsep

\begin{tabular}{llll}
\hline No & Aspek yang Dinilai & Ya & Tidak \\
\hline 1 & Kebenaran konsep Efek Rumah Kaca & $\sqrt{ }$ & \\
2 & Kebenaran konsep Pemanasan Global & $\sqrt{ }$ & \\
3 & Kebenaran konsep Dampak pemanasan global & $\sqrt{ }$ & \\
4 & Kebenaran konsep Upaya Penanggulangan & $\sqrt{ }$ & \\
\hline
\end{tabular}

Hasil uji kelayakan isi pada aspek kebenaran fakta dan konsep materi mendapatkan nilai persentase kelayakan sebesar $100 \%$. Berdasarkan hasil validasi dapat dinyatakan bahwa semua fakta dan konsep yang ada di dalam materi adalah sangat valid dan materi yang ada pada Paket IPA Terpadu sudah sesuai.Uji kelayakan paket IPA terpadu dalam meningkatkan kemampuan berpikir kreatif siswa menghasilkan data kuantitatif yang dapat dilihat pada Tabel 3.

Tabel 3. Hasil Uji Kelayakan Paket IPA Terpadu dalam Meningkatkan Kemampuan Berpikir Kreatif Siswa

\begin{tabular}{lll}
\hline No & Aspek yang Dinilai & $\begin{array}{l}\text { Persentase } \\
\text { Rata-rata } \\
\text { (\%) }\end{array}$ \\
\hline 1 & $\begin{array}{l}\text { Penyajian masalah yang relevan untuk mendorong } \\
\text { kemampuan siswa mengemukakan gagasan/ jawaban yang } \\
\text { benar sebanyak-banyaknnya }\end{array}$ & 80,00 \\
\hline 2 & $\begin{array}{l}\text { Mendorong kemampuan siswa untuk menggunakan } \\
\text { pemikiran yang berbeda dalam menyelesaikan masalah }\end{array}$ & 90,00 \\
3 & $\begin{array}{l}\text { Mendukung siswa untuk memberikan gagasan yang } \\
\text { berbeda/ unik } \\
\text { Mendorong siswa memberikan gagasan secara rinci dan } \\
\text { detail }\end{array}$ & 90,00 \\
\end{tabular}


Uji kelayakan penyajian buku siswa Paket IPA Terpadu menghasilkan data kuantitatif yang dapat dilihat pada Tabel 4.

Tabel 4. Hasil Uji Kelayakan Penyajian Buku Siswa

\begin{tabular}{lll}
\hline No & Aspek yang Dinilai & $\begin{array}{l}\text { Persentase } \\
\text { Rata-rata } \\
\mathbf{( \% )}\end{array}$ \\
\hline 1 & Keruntutan Konsep & 80,00 \\
2 & Kekonsistenan Sistematika & 80,00 \\
3 & Keseimbangan antar bab & 80,00 \\
4 & Berpusat pada siswa & 80,00 \\
5 & Variasi penyajian & 72,40 \\
6 & Halaman depan (Cover) & 76,80 \\
7 & Kata Pengantar & 80,00 \\
8 & Sistematika Paket & 70,00 \\
9 & Daftar isi & 90,00 \\
10 & Peta Konsep dan Peta Jalinan Materi & 70,00 \\
11 & Tujuan dan Indikator Pembelajaran & 80,00 \\
12 & Materi Pembelajaran & 81,60 \\
13 & Kegiatan Belajar Siswa & 83,20 \\
14 & Rangkuman & 86,80 \\
15 & Aplikasi Konsep & 82,40 \\
16 & Uji Pemahaman & 80,00 \\
17 & Glosarium & 80,00 \\
18 & Daftar Pustaka & 80,00 \\
\hline Rerata & $\mathbf{7 9 , 6 0}$ \\
\hline
\end{tabular}

Berdasarkan hasil uji kelayakan isi, kelayakan paket IPA terpadu dalam meningkatkan kemampuan berpikir kreatif siswa dan kelayakan penyajian Paket IPA Terpadu didapatkan persentase rata-rata sebesar $80,93 \%$ sehingga dapat dinyatakan bahwa buku siswa Paket IPA Terpadu layak, namun perlu direvisi terlebih dahulu sebelum diuji keefektivitasannya. Kegiatan revisi produk dilakukan berdasarkan data kualitatif hasil validasi media berupa komentar/saran. Komentar/saran yang diperoleh meliputi; 1) perlu menambahkan ranah sikap yang ditun-tut KD, 2) perlu menambahkan kata pengantar sebelum simulasi efek rumah kaca, 3) perlu perbaikan redaksi kata pada pengantar kegiatan "Mari Berpendapat", 4) perlu memperjelas konsistensi sistematika paket karena tulisan kurang terbaca dan sulit untuk dipahami. Selanjutnya dilakukan kegiatan revisi produk berdasarkan kometar/ saran dan dihasilkanlah Paket IPA Terpadu yang layak dan valid dengan perbaikan yang meliputi; 1) penambah-an ranah sikap sesuai KD, 2) menambahkan kata pengantar sebelum kegiatan simulasi efek rumah kaca, 3) memperbaiki redaksi kata pada pengantar kegiatan "Mari Berpendapat" dengan tepat dan 4) memperjelas sistematika paket menjadi lebih mudah untuk dibaca.

Uji kelayakan panduan guru Paket IPA Terpadu meliputi kesesuaian materi dengan kebutuhan guru, penyajian dan kelengkapan penyajian komponen buku 
panduan guru. Uji kelayakan panduan guru Paket IPA Terpadu menghasilkan data kuantitatif yang dapat dilihat pada Tabel 5.

Tabel 5. Hasil Uji Kelayakan Penyajian Buku Panduan Guru

\begin{tabular}{lll}
\hline No & Aspek yang Dinilai & $\begin{array}{l}\text { Persentase } \\
\text { Rata-rata (\%) }\end{array}$ \\
\hline 1 & Cakupan Materi & 70,00 \\
2 & Relevansi Materi & 90,00 \\
3 & Kemudahan & 80,00 \\
4 & Kesederhanaan & 80,00 \\
5 & Kejelasan & 90,00 \\
6 & Halaman depan (Cover) & 80,00 \\
7 & Kata Pengantar & 90,00 \\
8 & Daftar isi & 75,00 \\
9 & Peta Konsep dan Peta Jalinan Materi & 80,00 \\
10 & Tujuan dan Indikator Pembelajaran & 90,00 \\
11 & Materi Pokok & 90,00 \\
12 & Strategi Pembelajaran & 73,20 \\
13 & Teknik Penilaian & 86,80 \\
14 & Tes Evaluasi & 73,20 \\
15 & Kunci Jawaban & 76,80 \\
16 & Daftar Pustaka & 90,00 \\
\hline Rerata & & $\mathbf{8 2 , 2 0}$ \\
\hline
\end{tabular}

Berdasarkan hasil uji kelayakan isi Paket IPA Terpadu didapatkan skor persentase rata-rata sebesar $82,20 \%$ sehingga dapat dinyatakan bahwa buku panduan guru Paket IPA Terpadu sangat layak, namun perlu direvisi terlebih dahulu sebelum digunakan. Kegiatan revisi produk dilakukan berdasarkan data kualitatif hasil validasi media berupa komentar/saran. Komentar/saran yang diperoleh meliputi; 1) warna cover didominasi warna cerah, dan 2) perlu menambahkan panduan pengelolaan kelas saat pembelajaran menggunakan model learning cycle 5E. Selanjutnya dilakukan kegiatan revisi produk berdasarkan kometar/saran dan dihasilkanlah Paket IPA Terpadu yang layak dan valid dengan perbaikan yang meliputi; 1) menyeimbangkan proporsi warna terang dan gelap pada cover buku guru, dan 2) menambahkan panduan pengelolaan kelas untuk memudahkan guru dalam proses pembelajaran.

\subsection{Hasil Uji Keterbacaan}

Uji keterbacaan media dilakukan oleh kepada 10 siswa kelas VII SMP di kecamatan Turen. Penilaian uji keterbacaan oleh siswa terdiri dari penyajian dan manfaat paket IPA Terpadu bagi siswa. Kegiatan uji keterbacaan oleh siswa menghasilkan data kuantitatif yang dapat dilihat pada Tabel 6.

Tabel 6. Hasil Uji Keterbacaan oleh Siswa

\begin{tabular}{lll}
\hline No & Aspek yang Dinilai & Persentase Rata-rata (\%) \\
\hline 1 & Cover Buku & 92,40 \\
2 & Sistematika Paket & 82,00 \\
3 & Daftar isi & 86,00 \\
4 & Peta Konsep & 90,00 \\
\hline 5 & Apersepsi & 91,00
\end{tabular}




\begin{tabular}{lll}
6 & Kegiatan Siswa & 91,00 \\
7 & Uraian Materi & 92,00 \\
8 & Rangkuman & 88,00 \\
9 & Aplikasi Konsep & 90,00 \\
10 & Uji Pemahaman & 90,00 \\
11 & Glosarium & 78,00 \\
12 & Manfaat & 95,40 \\
\hline Rerata & $\mathbf{8 8 , 8 0}$ \\
\hline
\end{tabular}

Berdasarkan hasil uji keterbacaan oleh siswa didapatkan skor persentase rata-rata sebesar $88,80 \%$ sehingga dapat dinyatakan bahwa media sangat layak untuk digunakan. Data kualitatif yang diperoleh berupa komentar/saran. Komentar/saran yang diperoleh meliputi, 1) sistematika paket kurang jelas, 2) glosarium kurang lengkap. Selanjutnya dilakukan kegiatan revisi produk berdasarkan kometar/saran dan dihasilkanlah Paket IPA Terpadu yang layak dengan sistematika paket yang jelas dan glosarium yang lengkap.

\section{Simpulan}

\subsection{Kesimpulan}

Penelitian pengembangan yang dilakukan telah menghasilkan produk berupa Paket IPA Terpadu untuk siswa SMP/MTs kelas VII Tema Pemanasan Global. Paket IPA Terpadu yang dihasilkan berupa buku siswa dan buku panduan guru berbasis learning cycle 5E untuk meningkatkan kemampuan berpikir kreatif siswa. Kegiatan dan soal permasalahan yang disajikan diran-cang khusus untuk membantu meningkatkan kemampuan berpikir kreatif siswa. Model learning cycle digunakan untuk memancing siswa mengemukakan pendapat serta gagasannya agar mempermudah dalam membangun konsep secara mandiri.

Berdasarkan hasil validasi uji kelayakan isi, produk yang dikembangkan memiliki persentase kelayakan sebesar $79,20 \%$ sedangkan penilaian para ahli tentang kemampuan Paket IPA Terpadu untuk mening-katkan kemampuan berpikir kreatif memiliki persentase sebesar $84,00 \%$. Untuk uji kelayakan penyajian Paket IPA Terpadu memiliki persentase sebesar $79,60 \%$ dan uji kelayakan Panduan guru memiliki persentase sebesar $82,20 \%$. Dari keempat penilaian tersebut, rata-rata persentase yang diperoleh adalah $81,20 \%$ serta hasil validitas kebenaran fakta dan konsep 100\% yang menunjukkan bahwa Paket IPA Terpadu yang dikem-bangkan sangat layak untuk diuji efektivitasannya agar dapat digunakan dalam proses pembelajaran. Berdasar-kan hasil uji keterbacaan yang dilakukan kepada 10 siswa SMP kelas VII diperoleh persentase kelayakan sebesar $88,80 \%$ sehingga dapat dinyatakan bahwa paket yang dikembangkan sangat layak untuk digunakan. Sehingga dapat disimpulkan bahwa penelitian dan pengembangan ini menghasilkan produk berupa Paket IPA Terpadu berbasis Learning Cycle 5E untuk siswa SMP/MTs kelas VII Tema Pemanasan Global yang layak dan valid.

\subsection{Saran}

Saran yang diberikan pada penelitian selanjutnya adalah agar memperkaya modifikasi kegiatan siswa beserta soal-soal evaluasi sehingga sepenuhnya dapat mencakup aspek berpikir kreatif dan dapat memaksimalkan peningkatan kemampuan berpikir kreatif siswa. Perlu juga melakukan uji empiris terhadap soal- 
soal yang dibuat agar soal sesuai standar yang telah ditentukan. Uji empiris dilakukan untuk mengetahui keefektifan paket dalam pembelajaran IPA dan meningkatkan kemampuan berpikir kreatif siswa.

\section{Daftar Rujukan}

Adisendjaja, Y. H., \& Romlah, O. (2007). Analisis buku ajar sains berdasarkan literasi ilmiah sebagai dasar untuk memilih buku ajar sains (Biologi). In Disampaikan dalam Seminar Pendidikan Nasional di Jurusan Pendidikan Biologi FMIPA (pp. 25-26).

Asfuriyah, S., \& Nuswowati, M. (2015). Pengembangan majalah sains berbasis contextual learning pada tema pemanasan global untuk meningkatkan minat belajar siswa. Unnes Science Education Journal, 4(1).

Astutik, S. (2012). Meningkatkan hasil belajar siswa dengan model siklus belajar (learning cycle 5e) berbasis eksperimen pada pembelajaran sains di sdn patrang i jember.Jurnal Ilmu Pendidikan Sekolah Dasar, 1(2), 143-153.

Bahtiar, E. T. (2015, October). Penulisan bahan ajar. In Artikel disajikan dalam kegiatan Conference Paper di Bogor.

Branch, R. M. (2009). Instructional design: The ADDIE approach (Vol. 722). Springer Science \& Business Media.

Hendri, S., \& Defianti, A. (2015). Membentuk Keterampilan Argumentasi Siswa Melalui Isu Sosial Ilmiah dalam Pembelajaran Sains. Prosiding Simposium Inovasi dan Pembelajaran Sains.

Indonesia, P. M. L. H. R. (2019). Nomor 05 Tahun 2013 tentang Pedoman Pelaksanaan Program Adiwiyata.

Utami Munandar, S. C. (1999). Kreativitas dan Keberbakatan. Jakarta: PT Gramedia Pustaka Utama.

Rahayu, S. (2015). Meningkatkan profesionalisme guru dalam mewujudkan literasi sains siswa melalui pembelajaran kimia/IPA berkonteks isu-isu sosiosaintifik (socioscientific issues). Semnas Pendidikan Kimia \& Sains Kimia di Fakultas Pendidikan MIPA FKIP Universitas Negeri Cendana.

Sadia, I. W. (2014). Model-model pembelajaran sains konstruktivistik. Yogyakarta: Graha Ilmu.

Santika, A. M., Gusrayani, D., \& Jayadinata, A. K. (2016). Penerapan model pembelajaran learing cycle terhadap kemampuan berpikir kreatif siswa pada materi perubahan lingkungan. Jurnal Pena Ilmiah, 1(1), 571-580.

Santoso, B. (2011). Pengembangan materi geografi integrasi pemanasan global (global warming) dengan metode problembased learning pada kelas XI di SMA N 1 Suruh. JPP, 1(2).

Sari, D. P. (2014). Pengembangan Perangkat Pembelajaran dengan Model Learning Cycle pada Materi Suhu dan Perubahannya untuk Siswa SMP Kelas VII (Doctoral dissertation, State University of Surabaya)

Sari, O. N., Soekamto, H., \& Astina, I. K. (2014). Pengaruh Model Pembelajaran Learning Cycle 5E terhadap Kemampuan Berpikir Kritis Siswa Pada Mata Pelajaran Geografi. Jurnal Online Universitas Negeri Malang (http://jurnal-online. um. ac. id/article/do/detail-article/1/41/1566) diakses, 26-11.

Subiantoro, A. W., Aryanti, N. A., Rifai, M., \& Ahmad, J. K. (2012). Socio-Scientific Issues-Based Instruction dalam Pelajaran Biologi Lingkungan dan Pengaruhnya Terhadap Reflective Judgment dan Penguasaan Konsep Siswa Kelas X Madrasah Mu'allimin Muhammadiyah Yogyakarta. Laporan Penelitian Dosen Yunior Anggota Pusdi Tahun Anggaran 2012.

Sumarni, W. (2010). Penerapan learning cycle sebagai upaya meningkatkan keterampilan generik sains inferensia logika mahasiswa melalui perkuliahan praktikum kimia dasar. Jurnal Inovasi Pendidikan Kimia, 4(1).

Yuliani, F. (2015). Pengembangan buku saku materi pemanasan global untuk SMP (Doctoral dissertation, universitas negeri semarang). 